\title{
In Defense of Fault in Defamation Law
}

Despite large-scale revisions in the past fifteen years, ${ }^{1}$ the law of defamation ${ }^{2}$ remains unpolished and incomplete. These rough edges threaten to undermine the ends sought by the Supreme Court in its radical rewriting of the law. In particular, when the Court has formulated standards of journalistic care in the libel area, it has failed to address the evidentiary dimension of these standards. This omission

1. Prior to New York Times Co. v. Sullivan, 376 U.S. 254 (1964), the prevention and punishment of libelous statements was thought "never ... to raise any Constitutional problem," Chaplinsky v. New Hampshire, 315 U.S. 568, 572 (1942). In Sullivan, the Court for the first time recognized the need to reconcile the law of defamation with the First Amendment. 376 U.S. at 279. Sullivan held that a public official could recover in a defamation action only on a showing of "actual malice," defined as knowledge of a statement's falsity or reckless disregard of its truth. Id. at 279-80. In Curtis Publishing Co. v. Butts, 388 U.S. 130 (1967), five justices extended the actual malice rule to defamation suits by public figures. Id. at 164-65 (Warren, C.J., concurring in result); id. at 170-72 (Black, J., dissenting, joined by Douglas, J.); id. at $172-74$ (Brennan, J., dissenting, joined by White, J.). A plurality of the Court later adopted the actual malice rule for plaintiffs involved "in an event of public or general concern." Rosenbloom v. Metromedia, Inc., 403 U.S. 29, 52 (1971) (plurality opinion of Brennan, J.).

In Gertz v. Robert Welch, Inc., 418 U.S. 323 (1974), the Court rejected Rosenbloom and restricted the actual malice rule to defamation suits by public officials or public figures. Id. at 346. But the Court also required private individuals, regardless of their involvement in matters of public interest, to demonstrate fault on the part of the defendant for recovery of actual damages and to demonstrate actual malice for recovery of punitive or presumed damages. Id. at 347-50. Since Gertz, the Court has focused primarily on refining the distinction between public and private figures. See, e.g., Time, Inc. v. Firestone, 424 U.S. 448, $453-55$ (1976) (wealthy socialite not public figure for purpose of report on her divorce); Wolston v. Reader's Digest Ass'n, 47 U.S.L.W. 4840, 4842-43 (U.S. June 26, 1979) (person who engages in criminal conduct not automatically public figure for purposes of comment on his conviction); Hutchinson v. Proxmire, 47 U.S.L.W. 4827, 4834 (U.S. June 26, 1979) (neither successful application for Federal funds nor postlibel access to press renders plaintiff public figure). For a description and analysis of the public figure aspect of defamation law, see Note, The Edilorial Function and the Gertz Public Figure Standard, 87 YALE L.J. 1723 (1978). In contrast to public figure scrutiny, the meaning of the terms "fault" or "actual malice" has received little attention. Numerous courts since Gertz have applied the standards to specific situations. See, e.g., Time, Inc. v. Firestone, 424 U.S. 448, 459 (1976) (fault); Orr v. Argus-Press Co., 586 F.2d 1108, 1116-17 (6th Cir. 1978) (actual malice); Dickey v. CBS Inc., 583 F.2d 1221, 1227-29 (3d Cir. 1978) (actual malice). However, there has been little theoretical analysis of either the fault or actual malice standard. This Note will explore this more neglected side of the Gertz opinion.

2. A defamatory communication has been defined as an attack on a person's character that tends "to diminish the esteem, respect, goodwill or confidence" in which he is held, "or to excite adverse, derogatory or unpleasant feelings or opinions against him." W. Prosser, Handiook of The LaW of TORTs 739 (4th ed. 1971). The law of defamation manifests society"s "pervasive and strong interest in preventing and redressing attacks upon reputation." Rosenblatt v. Baer, 383 U.S. 75, 86 (1966). 
undermines press $^{3}$ freedom by inducing constitutionally unwarranted self-censorship, ${ }^{4}$ permitting a judge or jury to penalize unpopular speech, and discouraging potential defamation plaintiffs from taking steps to mitigate reputational harm.

This Note proposes, as a supplement to existing standards of care, an evidentiary rule limiting inquiry at defamation proceedings to the circumstances confronting the journalist ${ }^{5}$ as he sends an article to press. Focusing only on knowledge the journalist reasonably could have ascertained would eliminate much of the uncertainty from present standards, minimize the risk posed to unpopular speech, and provide an incentive to potential libel plaintiffs to prevent false tarnishing of their reputations.

\section{Gertz: A New Constitutional Balance}

Gertz v. Robert Welch, Inc. ${ }^{8}$ reversed a decade-long trend of Supreme Court decisions expanding the categories of defamation plaintiffs who

3. The term "press" includes members of both the print and broadcast media. See Gertz v. Robert Welch, Inc., 418 U.S. 323, 346-50 (1974) (repeated references to "publishers and broadcasters"). In analyzing current defamation standards, this Note focuses on the difficulties facing the institutional press; its proposed remedy, however, also may be applied to suits involving nonmedia defendants. See note 62 infra (proposed rule does not define special privilege for institutional press).

4. The term "self-censorship" has two meanings. In its descriptive sense, "self-censorship" occurs whenever a journalist refrains from publishing material for legal reasons. See Anderson, Libel and Press Self-Censorship, 53 TEx. L. REv. 422, 430-31 (1975). Because laws sometimes are intended to curtail speech injurious to other values, see, e.g., Miller v. California, 413 U.S. 15, 24-25 (1973) (establishing obscenity standards), this type of self-censorship may be acceptable, see Herbert v. Lando, 99 S. Ct. 1635, 1646 (1979) ("[I]f the claimed inhibition flows from the fear of damages liability for publishing knowing or reckless falsehoods, those effects are precisely what New York Times and other cases have held to be consistent with the First Amendment."); Curtis Publishing Co. v. Butts, 388 U.S. 130, 150 (1967) (plurality opinion of Harlan, J.) (First Amendment freedoms limited by sanctions designed to safeguard others' interests). In its normative sense, however, "self-censorship" refers to a needless restraint on First Amendment frecdoms. Statutory restraints in the name of a competing value that inhibit speech more than is necessary to protect that value are unconstitutional. Gooding v. Wilson, 405 U.S. 518,522 (1972) ("the statute must be carefully drawn or be authoritatively construed to punish only unprotected speech and not be susceptible of application to protected expression"). A similar rule has been announced to govern judicial restraints on specch in the defamation area. See Gertz v. Robert Welch, Inc., 418 U.S. 323, 349 (1974) ("It is ... appropriate to require that state remedies for defamatory falsehood reach no farther than is necessary to protect the legitimate interest involved."); New York Times Co. v. Sullivan, 376 U.S. 254, 265 (1964) (First Amendment encompasses state court applying common law of defamation in civil proceeding).

5. This Note concentrates on the journalist as the prime victim of legally induced self-censorship, but the term "journalist" is intended to include all those in a media organization who contribute to publication decisions.

6. 418 U.S. 323 (1974). 


\section{Defamation Law}

could recover only upon proof of the defendant's "actual malice."7 The Gertz Court held that the plaintiff was neither a public official nor a public figure, and thus that the lower courts had erred in applying the actual malice rule; ${ }^{8}$ it also went further, however, holding that states could define for themselves the appropriate standard of liability for a publisher or broadcaster charged with libel of a private individual, so long as the states did not impose liability without fault, that is, adopt a standard of strict liability. ${ }^{\circ}$ In addition, the Court limited recovery of damages, absent a showing of actual malice, to that necessary to compensate "actual injury." 10

The Gertz holding advanced prior law on three major fronts. First, Gertz recognized that a rule of strict liability inhibits press freedom even when applied in defamation suits by private individuals. ${ }^{11}$ Under such a rule, the press can avoid liability only by ensuring that all defamatory publications are truthful. ${ }^{12}$ Yet because occasional errors are inevitable, the press can completely avoid liability only by not publishing defamatory statements. ${ }^{13}$ Gertz held that a legal standard inducing such self-censorship violates the First Amendment. ${ }^{14}$

7. According to the original formulation of the term, see note I supra, a statement is made with actual malice if delivered "with knowledge that it was false or with reckless disregard of whether it was false or not." New York Times Co. v. Sullivan, 376 U.S. 254, 279-80 (1964). Subsequent Court decisions stressed the subjective aspect of the actual malice test. See, e.g., St. Amant v. Thompson, 390 U.S. 727, 731 (1968) (there must be sufficient evidence to conclude that "defendant in fact entertained serious doubts as to the truth of his publication"); cf. Herbert v. Lando, 99 S. Ct. 1635, 1646 (1979) (direct evidence of reckless disregard for truth entails inquiry into "thoughts, opinions and conclusions" of defendant); Gertz v. Robert Welch, Inc., 418 U.S. 323, 334 n.6 (1974) (stating that St. Amant "equated reckless disregard of the truth with subjective awareness of probable falsity").

8. Gertz v. Robert Welch, Inc., 418 U.S. 323, 352 (1974).

9. Id. at 347 .

10. Id. at 349. The Court said actual injury was "not limited to out-of-pocket loss," but included "impairment of reputation and standing in the community, personal humiliation, and mental anguish and suffering." $I d$. at 350. The Court found, however, that requiring the press to pay presumed and punitive damages "unnecessarily exacerbates the danger of media self-censorship" because these damages bear little or no relation to states' legitimate interest in compensating actual injury. Id. at 349-50.

11. Id. at 340. The Court said that a rule of strict liability fails "to assure to the frecdoms of speech and press that 'breathing space' essential to their fruitful exercise." Id. at 342 (quoting NAACP v. Button, 371 U.S. 415, 433 (1963)).

12. Although the numerous privileges to defamation recognized at common law often allayed in practice the severity of a strict liability rule, only the defense of truth sheltered the press from liability when these privileges did not apply. See W. Prosser, supra note 2, at 776-99 (outlining six qualified and six absolute defamation privileges, and truth defense); Anderson, supra note 4, at 443 (many common-law privileges frequently required proof similar to fault).

13. 418 U.S. at 340 .

14. Id. The First Amendment protects the flow of truthful information to the public. See Curtis Publishing Co. v. Butts, 388 U.S. 130, 147 (1967) (plurality opinion of Harlan, J.) (quoting Thornhill v. Alabama, 310 U.S. 88, 102 (1940)) (freedom of discussion embraces "all issues about which information is needed or appropriate to enable the mem- 
When Gertz proscribed strict liability and required states to premise defamation recovery on a showing of fault, the Court implicitly recognized the desirability of permitting journalists to publish defamatory statements without relinquishing control over subsequent liability. ${ }^{15}$ A fault standard enables a journalist to ensure freedom from liability by tailoring his conduct to meet legal requirements of thoroughness and care; ${ }^{10}$ if requisite standards are met, the journalist can publish defamatory statements without fear that an unavoidable error will create liability. ${ }^{17}$ The flow of truthful information to the public thus continues relatively unimpaired.

bers of society to cope with the exigencies of their period"). The press plays a central role in informing citizens unable to derote themselves full time to the gathering of facts. See Cox Broadcasting Corp. v. Cohn, 420 U.S. 469, 491-92 (1975) (limited citizen resources to observe operations of government first hand places great responsibility on press to report governmental activities fully and accurately). Undue press self-censorship thus directly impedes the pursuit of democratic self-government. See New York Times Co. v. Sullivan, 376 U.S. 254, 279 (1964) (self-censorship under strict liability "dampens the vigor and limits the variety of public debate"). Moreover, because postponing the dissemination of information can have irreversible consequences, even temporary restraints on speech may be constitutionally intolerable. See Nebraska Press Ass'n v. Stuart, 427 U.S. 539,559 (1976) (burden on government of justifying prior restraint not reduced by temporary nature of restraint).

15. The Court introduced the fault requirement in order to protect the press in any defamation suit from the hazards of strict liability. Gertz v. Robert Welch, Inc., 418 U.S. 323, 347 (1974). The Court justified its holding by pointing to the necessity of "protect[ing] some falsehood in order to protect speech that matters." Id. at 34l. Sullivan had advanced a similar argument to justify applying the actual malice rule to defamation suits by public officials. 376 U.S. at 271-72.

As a standard of care, fault parallels, in less stringent form, the proof requirements of the actual malice rule. See Anderson, supra note 4, at 461-62 (Gertz and Sullivan standards "functionally analogous, ... . differing only in the quantum of fault required"). In analyzing deviations from a fault-based standard of care, this Note identifies problems common to both the actual malice and fault rules.

16. In Sullivan, Justices Black and Douglas adhered to the absolutist position that permitting defamation recovery in any form is unconstitutional. 376 U.S. at 293 (Black, $\mathrm{J}$., concurring). Although this position would restrict speech even less than a standard of due care, no other Justice has ever embraced it. See Herbert v. Lando, 99 S. Ct. 1635, 1649 (1979) (Court has regularly found complete immunity from defamation liability "untenable construction of the First Amendment"). Because the absolutist position ignores "the legitimate interest in redressing wrongful injury," Gertz v. Robert Welch, Inc., 418 U.S. 323, 342 (1974), this Note will not consider it as an appropriate constitutional balance.

17. Early in its constitutional discussion of defamation, the Court illustrated the journalistic care required by the actual malice standard. See Curtis Publishing Co. v. Butts, 388 U.S. 130, 157-59, 165, 169-70 (1967) (plurality opinion of Harlan, J.) (Warren, C.J., concurring in result) (it is at least actual malice to publish without verification serious charges by unreliable source when no time pressure exists; it is not actual malice to publish damaging article by reliable correspondent when there is time pressure and story is internally consistent). Although less frequently addressed, the requirements of the fault standard are gradually becoming' clarified. See, e.g., Time, Inc. v. Firestone, 424 U.S. 448,459 (1976) (fault when most damaging from among several conceivable interpretations is chosen unless choice is true); Lake Havasu Estates, Inc. v. Reader's Digest Ass'n, 441 F. Supp. 489, 493 (S.D.N.Y. 1977) (not fault to publish story without checking whether others had same name as subject of article). 
Second, by requiring a fault-based standard for liability, the Gertz Court acknowledged that unpopular speech is threatened when legal rules are tied to the content of a statement. ${ }^{18}$ In pursuing the constitutional goal of diverse public debate, the First Amendment protects speech regardless of its popularity. ${ }^{19}$ A strict liability rule jeopardizes this diversity by conditioning legal sanctions on the false content of defamatory statements, thus making the content of a publication central to the defamation trial. Basing liability on a standard of conduct safeguards diversity by focusing on a journalist's actions in publishing a statement rather than on the content of the statement itself. ${ }^{20}$

In Rosenbloom $v$. Metromedia, Inc., ${ }^{21}$ a three-judge plurality of the Court had ignored the importance of content-neutrality in the First Amendment area by extending the actual malice rule to defamation suits concerning matters of "public or general concern." 22 Gertz returned to content-neutrality by rejecting assessment of the public interest as a legitimate test for defining the scope of the actual malice rule. The Court reasoned that a content-based standard would involve judges in the dangerous business of determining " what information is relevant to self-government." "23 Nor did the Gertz Court believe that concern for unpopular speech was more safely entrusted to jurors; the Court limited juries' power to award punitive damages because they would be "free to use their discretion selectively to punish expressions of unpopular views." ${ }^{24}$ Each ruling reflected the Court's opinion that

18. See 418 U.S. at 346 (unacceptable to determine liability on basis of public-interest test). The goal of protecting speech from suppression on the basis of unpopular content is a theme sounded repeatedly in the defamation cases. See, e.g., Curtis Publishing Co. v. Butts, 388 U.S. 130, 150-51 (1967) (plurality opinion of Harlan, J.) (unacceptable to impose sanctions on basis of what one thinks or publishes); New Yort: Times Co. v. Sullivan, 376 U.S. 254, 276 (1964) (restraint on criticism of government inconsistent with First Amendment); cf. Police Dep't v. Mosley, 408 U.S. 92, 95 (1972) ("[A]bove all else, the First Amendment means that government has no power to restrict expression because of its message, its ideas, its subject matter, or its content.")

19. New York Times Co. v. Sullivan, 376 U.S. 254, 266 (1964) (First Amendment attempts "to secure "the widest possible dissemination of information from diverse and antagonistic sources.' ") (quoting Associated Press v. United States, 326 U.S. 1, 20 (1943)).

20. See Curtis Publishing Co. v. Butts, 388 U.S. 130, 153 (1967) (plurality opinion of Harlan, J.) ("Impositions based on misconduct can be neutral with respect to content of the speech involved .... ."); cf. Monitor Patriot Co. v. Roy, 401 U.S. 265, 276-77 (1971) (in contrast to standard of care, standard of "relevance" unlikely to be neutral with respect to content of speech and holds danger of becoming instrument of suppression of vehement attacks).

21. 403 U.S. 29 (1971).

22. Id. at $43-44$ (plurality opinion of Brennan, J.).

23. Gertz v. Robert Welch, Inc., 418 U.S. 323, 346 (1974) (quoting Rosenbloom v. Metromedia, Inc., 403 U.S. 29, 79 (1971) (Marshall, J., dissenting)). The Gertz Court "doubt[ed] the wisdom of committing this task to the conscience of judges." 418 U.S. at 346.

24. 418 U.S. at 350 . 
undue focus on the content of a statement threatened to transform defamation law into a tool for suppressing unpopular speech rather than for redressing defamatory falsehood.

Finally, Gertz underscored the duty of the subject of a libelous article to invoke available self-help remedies when possible in order to mitigate defamatory harm. ${ }^{25}$ Thus, it varied the duty of care that a journalist owed the subject of a defamatory publication according to the subject's access to means of rebuttal. ${ }^{26}$ Because private individuals generally lack an effective forum for reply, ${ }^{27}$ they have a greater need for legal protection than do public figures. The Court responded to this need by requiring a lesser standard of proof for suits by private persons. ${ }^{28}$

Despite its major contributions to defamation law, Gertz failed to address several significant issues. Although the Court required a fault-based standard for liability, it failed to discuss the evidentiary requirements of such a standard; ${ }^{20}$ nor were the evidentiary requirements of the actual malice rule articulated with any greater precision than in previous cases. ${ }^{30}$ The Court continued to focus on defining various categories of defamation plaintiffs at the expense of explaining the substantive standards of liability applicable to these categories. ${ }^{31}$ Furthermore, although Gertz voiced a general preference in the First Amendment area for liability standards based on conduct rather than content, it applied this preference only to reject the public-interest test and to employ the fault and actual malice standards. The Court failed to recognize that current evidentiary practices also permit the content of a statement to influence a defamation proceeding. Finally, although

25. Gertz v. Robert Welch, Inc., 418 U.S. 323, 344 (1974). "Self-help" involves the use of "available opportunities to contradict the lie or correct the error and thereby to minimize its adverse impact on reputation." $I d$.

26. See id. (noting public figure's greater access to media and greater opportunity for rebuttal as partial justification for premising recovery on higher standard of proof). Elsewhere the Court has advanced a similar rationale. See Wolston $r$. Reader's Digest Ass'n, 47 U.S.L.W. 4840, 4841 (U.S. June 26, 1979); Curtis Publishing Co. v. Butts, 388 U.S. 130, 155 (1967) (plurality opinion of Harlan, J.).

27. Gertz v. Robert Welch, Inc., 418 U.S. 323, 344-45 (1974).

28. Although a public figure must prove actual malice in order to recover for defamatory falsehood, a private individual need demonstrate only fault. $I d$. at $342-48$. Mrr. Justice Harlan had earlier urged the same distinction. Rosenbloom v. Metromedia, Inc., 403 U.S. 29, 70-72 (1971) (Harlan, J., dissenting).

29. See Gertz v. Robert Welch, Inc., 418 U.S. 323, 347 (1974) (holding only that states cannot "impose liability without fault").

30. See id. at 342,349 (restating Sullivan formulation of actual malice).

31. See note 1 supra (recent defamation cases primarily address distinction between public and private figures). Other than contrasting the requisite standards of care with a rule of strict liability, see Gertz v. Robert Welch, Inc., 418 U.S. 323, 342, 347 n.10 (1974), the Court did nothing to define these standards except to invoke the verbal formulas of "fault" and "actual malice." 
the Court recognized a role for self-help in mitigating defamatory harm, it failed to provide incentives that would encourage full use of available remedies.

\section{Inadequacy of the Gertz Liability Rule}

Evidentiary practices in defamation law threaten to undermine the ends sought by Gertz. In contrast to the fault-based system on which it is theoretically modeled, current defamation law permits the ultimate falsity of a published account to play an improper role in the evaluation of journalistic care. Because evidence of falsity is admitted in defamation proceedings, present law impedes the flow of truthful information to the public, invites judges and juries to suppress unpopular speech, and provides no incentive for the subject of a defamatory statement to employ self-help remedies before publication.

\section{A. An Inducement to Self-Censorship}

Judges frequently fail to limit the evidence of falsity introduced by a libel plaintiff to that reasonably available to the journalist at the time of publication. ${ }^{32}$ As a result, the ultimate falsity of an article has an inordinate influence on the court's evaluation of whether a journalist exercised due care. In this way, defamation standards effectively become more stringent. For example, despite the subjective meaning of the term "knowledge" under the actual malice rule,"33 judges often combine the ultimate falsity of a report with a plaintiff's unilateral and unsubstantiated denial of its truth to impute "knowledge of falsity" on the part of the journalist, even though at the time of publication the journalist had encountered no factual evidence contradicting his article. ${ }^{34}$

32. See, e.g., Church of Scientology v. Dell Publishing Co., 362 F. Supp. 767, 770 (N.D. Cal. 1973); Indianapolis Newspapers, Inc. v. Fields, 254 Ind. 219, 222-23, 259 N.E.2d 651, 684, cert. denied, 400 U.S. 930 (1970) (separate opinion of Arterburn, J.). In Church of Scientology, the court admitted evidence of an expose's falsity although the evidence was released after publication. 362 F. Supp. at 770 . In Fields, the court permitted the plaintiff to introduce evidence of an article's falsity in order to prove actual malice without requiring him to demonstrate that the defendant newspaper knew or should have known of the evidence prior to publication. Although the jury was instructed to consider only prepublication evidence of falsity, the defendant noted that such a procedure amounted to "practically 'drowning' defendant and then attempting to revive him in the end by an instruction." 254 Ind. at $222-23,259$ N.E.2d at 684.

33. See note 7 supra (citing decisions interpreting actual malice rule).

34. See, e.g., Ammerman v. Hubbard Broadcasting, Inc., 91 N.M. 250, 255, 572 P.2d 1258, 1263 (1977), cert. denied, 436 U.S. 906 (1978) (including conclusory denial by plaintiff that charges were "absolutely false" as part of evidence that defendant had knowledge of falsity); Chase v. Daily Record, Inc., 83 Wash. 2d 37, 44-45, 515 P.2d 154, 158 (1973) 
Under a fault-based standard of care, the judge or jury should evaluate a journalist's conduct to determine whether he gave appropriate weight to information reasonably available at the time of publication. Permitting evidence of an article's ultimate falsity to reach the trier of fact, without regard to whether the evidence was practically available to the journalist at the time of publication, threatens to prejudice assessment of the journalist's conduct in favor of a finding of actual malice or fault. ${ }^{35}$ If the trier of fact succumbs to the prejudicial effect of this evidence, a journalist may be held accountable for a defamatory comment even though nothing he reasonably could have done at the time of publication would have revealed the falsity of the relevant statement. Holding a journalist legally responsible for factors outside his control conflicts with the premises of a fault-based standard. ${ }^{36}$

Under present law, the fear that information unavailable at the time of publication may subsequently emerge and cast a pall of falsity on the published article can discourage a journalist from making a defamatory statement regardless of his immediate assessment of its truth. The effectively tougher standards resulting from current evidentiary practices may induce increased self-censorship in the same way a change in the nominal standards would. ${ }^{37}$ Enlarging the risk of damage

(finding knowledge of falsity under actual malice rule on basis of ultimate falsity plus defendant's repeated but unsubstantiated prepublication denials). A conclusory denial by a plaintiff should not be sufficient to establish a journalist's actual malice. See note 61 infra. Because a standard of recklessness or negligence affords more judicial latitude than does the actual malice criterion, incorrect applications are more difficult to monitor. Nevertheless, misuse of evidence of ultimate falsity would render these other standards of care effectively more stringent as well.

35. See Restatement (SECOND) of ToRTs $\$ 580 B$, Comment $g$ (1976) (warning courts of jury tendency to decide defendant must have been negligent because it published defamatory communication); Anderson, supra note 4, at 465 ("Lawyers will be tempted to argue-and jurors to believe-that publishers and broadcasters do not innocently disseminate defamatory falsehoods.")

36. Imposing liability for an unforeseeable wrong is inconsistent with the Gertz goal of protecting the press so long as it exercises reasonable care. See Anderson, supra note 4, at 464-65; cf. W. Prosser, supra note 2, at 146 (negligence standards assess conduct, not consequences). Judicial decisions have stressed the need to separate the issues of truth and due care. See Rosenbloom v. Metromedia, Inc., 403 U.S. 29, 35, 55 (1971) (plurality opinion of Brennan, J.) (information disclosed to defendant after broadcast "has no probative value" on issue of due care); Kidder v. Anderson, 354 So. 2d 1306, 1309 (La.), cert. denied, 99 S. Ct. 105 (1978) (issue not ultimate falsehood of defamatory statements but whether newspaper reporter uttered them with actual malice).

37. Because instances of self-censorship are by definition never subject to defamation suits, the problem is impossible to monitor by reading decisions. A lack of reported examples of self-censorship therefore does not imply that the problem is nonexistent. Indecd, there is evidence such self-censorship by the press has occurred. See note 41 infra (describing example). Although it might seem odd that journalists regulate their activity according to the intricacies of evidentiary rules, the libel attorney is likely to 
payments $^{38}$ and legal fees ${ }^{39}$ increases the journalist's hesitation to print defamatory material. Moreover, even if the standards of fault and actual malice come to approximate a rule of strict liability only occasionally, uncertainty as to when this tightening of legal standards will occur may induce a similar reticence. ${ }^{40}$ In each case, a journalist can ensure nonliability only by refusing to publish defamatory statements: a journalist cannot be certain that, if his published article is ultimately erroneous, his reporting efforts will be deemed adequate. Such legal uncertainty provides a powerful incentive beyond that of a

bring home the impact of these rules as he reviews a proposed article. See Anderson, supra note 4, at 438 ("Post-Times censorship is not exactly self-censorship; it is more accurately censorship by libel lawyer because the pivotal factors in deciding whether to publish are ones that the press itself cannot fully evaluate.")

38. It has been argued that the size of a potential libel judgment is the most significant factor in inducing self-censorship. See, e.g., Rosenbloom v. Metromedia, Inc., 403 U.S. 29, 82 (197I) (Marshall, J., dissenting). Gertz sought to limit defamation awards by requiring proof of actual malice in order to recover presumed or punitive damages. 418 U.S. at 350 . Although this requirement may reduce substantially the number of punitive awards, its effect on presumed damages is less clear. Presumed or general damages traditionally functioned to compensate loss that was difficult to prove in monetary terms. See Restatement of Torts $\S 621$, Comment a (1938). Since Gertz, this task arguably has been assumed by damages compensating "actual injury" as it is liberally defined in that case. See note 10 supra (Gertz definition of "actual injury"); Time, Inc. v. Firestone, 424 U.S. 448, 475 n.3 (1976) (Brennan, J., dissenting) (criticizing actual injury award of $\$ 100,000$ for "mental suffering"). Moreover, even when damage is not presumed, provable monetary losses may assume immense proportions. See, e.g., Sierra Life Ins. Co. v. Magic Valley Newspapers, Inc., 4 MEdi L. REP. (BNA) 1689, 1692 (Idaho Dist. Ct. 1978) (awarding \$1.9 million for expenses and lost profits caused by defamatory statement).

39. The expense of defending a defamation suit may itself induce self-censorship. See Rosenbloom v. Metromedia, Inc., 403 U.S. 29, 52-53 (1971) (plurality opinion of Brennan, J.) (possibility of litigation causes speech to stay clear of unlawful zone); Hume, The Mayor, the Times, and the Lawyers, [MoRE], Aug. 1974, at 1, 17 (article not published because cost of defending libel suit might easily bankrupt magazine, even though magazine likely to have won); Dorfman, The Story Behind the Story, Reader (Chicago), Feb. 2, 1979, $\S 1$, at 1, 31 (one publication halted when libel suit explicitly threatened); cf. Anderson, supra note 4, at 437 (Sullivan privilege "operates at the wrong end of the litigation"; to prevent self-censorship, must protect press from cost of litigation). The impact of legal expenses may be strongest for small publications and effectively silence their coverage of defamatory matters. See Sprouse v. Clay Communication, Inc., 211 S.E.2d 674, 690-91 (W. Va.), cert. denied, 423 U.S. 882 (1975) (defamation legal expenses "repressive" for small newspapers); cf. Nebraska Press Ass'n v. Stuart, 427 U.S. 539,610 n.40 (1976) (Brennan, J., concurring in judgment) (quoting Letter of Editor and Publisher of Anniston (Ala.) Star, quoted in Brief for Washington Post Co. et al. as Amici Curiae 31-32) (legal expenses from attempt to impose prior restraint render "obedient silence" only alternative for small-town dailies).

40. See, e.g., Nimmer, The Right to Speak from Times to Time: First Amendment Theory Applied to Libel and Misapplied to Privacy, 56 CAlif. L. Rev. 935, 939 (1968) (absence of certainty in law particularly permicious where speech is concerned because it tends to deter all but most courageous); Wright, Defamalion, Privacy, and The Public's Right to Know, 46 TEx. L. Rev. 630, 634 (1968) (a speaker "steers clear of a barbed wire fence, but he stays even farther away if he is not sure exactly where the fence is"). In noting the chilling effect of uncontrolled presumed damage awards, Gertz implicitly recognized that once liability is found, legal uncertainty may induce self-censorship. See 418 U.S. at 349. 
fault or actual malice standard to shy away from treatment of potentially defamatory subjects. ${ }^{41}$ Yet the need for this type of self-censorship is precisely what Gertz sought to obviate in proscribing a strict liability rule. If evidentiary rules are fashioned to admit only evidence relevant to the determination of fault or actual malice, then only the selfcensorship explicitly required by defamation law is likely to occur. ${ }^{42} \mathrm{~A}$ journalist could largely control his exposure to liability by ensuring that his research conformed with requisite standards.

The danger that evidence released after publication will influence the effective standard of care is most acute when the subject of an article refuses to disclose evidence exclusively within his possession. Because no alternative source is available, ${ }^{43}$ a journalist in this situation must decide whether to publish a defamatory accusation without access to highly relevant information. Should the hidden evidence prove exculpatory and be admitted to a defamation proceeding, the risk of liability would be great; self-censorship in such instances is likely to be pronounced. Moreover, rather than encouraging the discovery of hidden facts, courts have actually penalized efforts to dig below apparent reality. ${ }^{44}$

41. See, e.g., Dorfman, supra note 39 , at 1 , col. 1. The legal uncertainty that arises from permitting information released after publication to influence the determination of fault contributed to a recent decision by Chicago magazine not to run an investigative story on the alleged CIA connections of several Chicago businessmen. The publisher's unease with the story began after one individual named in the article denied emphatically-though without substantiation-all charges levied against him and explicitly threatened suit. The magazine's efforts to ensure that it had conformed with legal standards of care were frustrated by the subject's refusal to disclose files in his possession that he claimed would prove exculpatory. Id. at 29-31. Had liability hinged exclusively on conduct, as it ostensibly does after Gertz, the magazine could have published the article with little risk of legal sanction so long as its reporters had behaved in accordance with the requisite standards of care. Nevertheless, the magazine's attorney felt compelled to warn of "the conventional learning" that if one of the potential plaintiffs is found to be a private individual and a negligence standard is applied, "the jury will decide for who[m]ever it thinks spoke the truth. One does not predict the outcome of situations like that, at least without having heard both sides' evidence." Letter from A. Daniel Feldman to Raymond Nordstrand, Publisher, Chicago magazine (June 16, 1978) (on file with Yale Law Journal). The subject's refusal to grant access to his files rendered this airing of both sides impossible. Immediately on receipt of the letter, the publisher decided not to run the story. Dorfman, supra note 39 , at 32.

42. Cf. Herbert v. Lando, 99 S. Ct. 1635,1647 (1979) (one aim of defamation law to deter those who publish defamatory falsehood with requisite culpability).

43. Both traditional and investigative reporters rely heavily on others for access to confidential information. See E. EPstein, BEyond FACr and Ficrion 9-11 (1975) (Traditional "[j]ournalists readily admit that they are dependent on others for privileged information and the ascertainment of facts in a controversial issue . . . "); P. Williaks, INVESTIGATIVE REPORTING AND EDITING 7-8 (1976) (“'I]nvestigative reporting . . . usually involves the gathering of important information which some person or agency is trying to keep secret.") As a result, an important but uncooperative source of information can severely hinder a reporter's quest for truth.

44. Courts have pointed to a muckraking intent to support a finding of a failure to meet the applicable standard of care. See, e.g., Curtis Publishing Co. v. Butts, 388 U.S. 


\section{B. The Threat to Unpopular Expression}

A central aim of defamation law is to protect the expression of a diversity of views. ${ }^{45}$ Gertz recognized that diversity is endangered whenever the trier of fact considers the content of an utterance. ${ }^{46}$ The court's judgment may then be used to censor unpopular speech rather than to protect a plaintiff's reputation. ${ }^{47}$ Yet despite this observation, current evidentiary rules make no effort to minimize the extent to which a trier of fact considers a statement's content. If evidence of the truth of a statement's content were admitted only to the extent it was probative of fault or actual malice, its impact on the trier of fact would be reduced and diversity of expression would be endangered no more than necessary under Gertz.

Even under Gertz, however, determination of fault or actual malice requires some inquiry into the content of a defamatory statement; a journalist's conduct can be evaluated only in light of his reactions to the content of available information. Once evidence of the content of a statement is admitted to a defamation proceeding, personal bias towards that content may influence the ultimate judgment. Because a

130, 158 (1967) (plurality opinion of Harlan, J.) (pointing to petitioner's policy of "sophisticated muckraking" as possible motive for its adjudged "stretching" of journalistic standards); Durso v. Lyle Stuart, Inc., 33 Ill. App. 3d 300, 305, 337 N.E.2d 443, 447 (1975) (identifying author's "exposé intent" and desire to "name names" as possible reasons for imposing liability for arguably reasonable error of confusing two individuals with same first and last names). To the extent that courts equate muckraking with malicious motives, it may be used to justify the application of a more stringent duty of care. See, e.g., Time, Inc. v. Firestone, 424 U.S. 448, 459 (1976) (arguably holding petitioner to strict liability standard because it chose to report most damaging interpretation of ambiguous document).

Moreover, the need for lengthy investigation that usually attends efforts to expose hidden information may increase a journalist's risk of liability. Courts often point to the lack of time pressure on the press as a factor in decisions favorable to defamation plaintiffs. See, e.g., Alioto v. Cowles Communications, Inc., 519 F.2d 777, 779 (9th Cir. 1975) (citing Montandon v. Triangle Publications, Inc., 45 Cal. App. 3d 938, 120 Cal. Rptr. 186, cert. denied, 423 U.S. 893 (1975)); cf. Bezanson, The New Free Press Guarantee, 63 VA. L. REv. 731, 743-44 (1977) (suggesting lack of urgency as partial explanation of Gertz decision).

45. See p. 1739 supra.

46. 418 U.S. 323,346 (1974).

47. Id. at 367 (Brennan, J., dissenting) (flexible standard of care creates danger jury will convert it into instrument for suppressing speech); cf. Time, Inc. v. Hill, 385 U.S. 374, 406 (1967) (Harlan, J., concurring in part) (determination of truth permits jury prejudice to institute system of censorship); BeVier, The First Amendment and Political Speech: An Inquiry Into the Substance and Limits of Principle, 30 Stan. L. Rev. 299, 327 (1978) (juries fail to protect minority viewpoints against exercise of governmental power supported by majority). For an example of an apparent attempt to suppress unpopular views through use of an unusually high damage award, see New York Times Co. v. Sullivan, 273 Ala. 656, 144 So. 2d 25 (1962), rev'd, 376 U.S. 254 (1964) (Alabama Supreme Court upholding jury award of $\$ 500,000$ for false defamation in paid advertisement describing racial confrontations). 
court's judgment may be coercively enforced, a threat to diversity inheres in any form of a defamation trial.

The defamation trial is an attempt to respond to a breakdown in the public marketplace of expression. If the truth naturally prevailed, defamatory harm would be minimal and the need for legal redress largely obviated. But the impact of an initial media statement may warp public perception and render attempts at rebuttal ineffective. ${ }^{48}$ The adversarial context of a defamation trial, then, provides a deliberative atmosphere that allows the defamation plaintiff to rebut injurious charges. ${ }^{49}$

If this atmosphere could be replicated without the coercive potential of the defamation trial, diversity values could be enhanced beyond the Gertz formula without sacrificing its protection of reputational interests. Harm caused by defamatory falsehood could be minimized without the potential for suppression, which resort to legal remedies inevitably entails. ${ }^{50}$

\section{A Lack of Self-Help Incentives}

Gertz continued to rely primarily on the damage award as a remedy for defamatory harm. ${ }^{51}$ Nevertheless, although its analysis of self-help was flawed in two ways, the Court recognized a role for self-help in mitigating reputational harm. ${ }^{52}$ First, the Court failed to provide the

48. See Gertz v. Robert Welch, Inc., 418 U.S. 323, 344 n.9 (1974) ("law of defamation is rooted in our experience that the truth rarely catches up with a lie"); AAFCO Heating \& Air Conditioning Co. v. Northwest Publications, Inc., 162 Ind. App. 671, 681, 321 N.E.2d 580, 587 (1974), cert. denied, 424 U.S. 913 (1976) (unlikely that published rebuttal will receive same degree of public attention as original defamation).

49. But see Fleming, Retraction and Reply: Alternative Remedies for Defamalion, 12 U. BRIT. Colum. L. REv. 15, 15 (1978) (legal refutation of libel not attended with much, if any, publicity and may occur "long after the libel has spread its poison").

50. A similar rationale underlies the reduced legal protection afforded the reputation of a public figure under the First Amendment. If a plaintiff is able to rebut a defamatory remark effectively, this self-help is preferable to legal redress. See Gertz v. Robert Welch, Inc., 418 U.S. 323, 344 (1974) (state interest in protecting reputation less as opportunity for rebuttal greater); Time, Inc. v. Hill, 385 U.S. 374, 407 (1967) (Harlan, J., concurring in part) ("[F]alsehood is more easily tolerated where public attention creates the strong likelihood of a competition among ideas.")

51. A monetary award, however, can never fully compensate the intangible loss of a falsely tarn:shed reputation. See Riesman, Democracy and Defamation: Control of Group Libel, 42 Colum. L. Rev. 727, 731 (1942) (emphasis on damages blinds courts to "intangibles of honor"). Moreover, the damages remedy is a poor foundation on which to reconcile reputational and First Amendment interests. See Fleming, supra note 49, at 15 (damages remedy exacerbates tension between protection of reputation and freedom of expression).

52. See Gertz v. Robert Welch, Inc., 418 U.S. 323, 344 (1974) (self-help minimizes adverse impact of falsehood on reputation); cf. Wolston v. Reader's Digest Ass'n, 47 U.S.L.W. 4840,4841 (1979) (access to channels of effective communication enables public figures "through discussion to counter criticism and expose the falsehood and fallacies of defamatory statements"). 
subject of a defamatory charge an incentive to employ this remedy. Indeed, if the subject displayed access to effective channels for rebuttal, he would be likely to confront at trial the more stringent proof requirements of the actual malice rule. ${ }^{53}$ Second, Gertz considered selfhelp only as a remedy after publication. The Court conceded that rebuttal subsequent to publication "seldom suffices to undo harm of defamatory falsehood," 54 yet it failed to explore more effective methods of preventing harm..$^{55}$ If present evidentiary standards were altered to admit to a defamation trial only the evidence available to the journalist at the time of publication, they would encourage use of self-help before publication and often avert reputational harm. This incentive would comport with Gertz's preference for self-help as a method for redressing reputational harm and institute the preventive dimension of the remedy left unexamined by the Court.

\section{Fault Reinforced: A Proposed Evidentiary Rule}

Present evidentiary standards subvert three major goals of Gertz. By admitting evidence of falsity without regard to its availability at the time of publication, these standards induce unwarranted self-censorship, increase the threat to unpopular speech, and undermine self-help incentives. A rule restricting admissibility to evidence reasonably within the reach of the journalist when he prepared the defamatory statement could remedy these weaknesses in current law and realize more fully the ends sought by Gertz.

\section{A. The Proposal}

The rules governing admissibility in a defamation proceeding should exclude all evidence that a plaintiff refused to disclose to the defendant in response to detailed defamatory charges and that was not otherwise reasonably available at the time of publication. Under this rule, a journalist would be responsible for considering all information reason-

53. See Gertz v. Robert Welch, Inc., 418 U.S. 323, 344 (1974) (one defining feature of public figure is opportunity for rebuttal); of. Wolston v. Reader's Digest Ass'n, 47 U.S.L.W. 4840, 4841 (U.S. June 26, 1979) (same).

54. 418 U.S. at 344 n.9.

55. Although extremely effective in averting reputational injury, Gertz clearly meant to outlaw such preventive strategies as maintaining a strict liability rule or allowing unrestrained punitive damages. See $i d$. at 347-50. Similarly, a prior restraint to enjoin publication of defamatory falsehood is forbidden by the First Amendment. See New York Times Co. v. United States, 403 U.S. 713, 714 (1971) (per curiam) (quoting Bantam Books, Inc. v. Sullivan, 372 U.S. 58, 70 (1963)) (" Any system of prior restraints [bears] a heavy presumption against its constitutional validity." ); Near v. Minnesota ex rel. Olson, 283 U.S. 697, 713 (1931) ("chief purpose of [First Amendment] to prevent previous restraints upon publication"). 
ably obtainable when he prepared the article. ${ }^{56}$ But the rule would shield him from accountability for information that the subject of an article refused to disclose and that the journalist could not reasonably have acquired elsewhere.

Application of this exclusionary rule should depend on two conditions. First, it should be triggered only if the journalist has presented to the subject the contents of an injurious charge ${ }^{57}$ and requested relevant information within the subject's exclusive control. ${ }^{58}$ The subject would thus be put on notice that, if he fails to cooperate, his legal remedies for defamation might be impaired. Second, the subject should be required to respond with no greater factual specificity than that with which the charges were presented. The journalist would thus be prevented from exploiting the rule to conduct a fishing expedition. ${ }^{50}$

56. For the purpose of evaluating availability, the term "journalist" includes those employees of a media entity, who, by the appropriate standard of care, should have had access to the relevant information. Cf. Gertz v. Robert Welch, Inc., 418 U.S. 323, 325-27 (1974) (examining conduct of managing editor).

57. The need for a journalist to initiate this confrontation with the subject would render the proposed rule inoperative in cases when danger to reputation is not reasonably apparent to the journalist at the time of publication. Although Gertz leaves the issue open, it implies that liability for factual misstatements in such situations may be constitutionally impermissible. See id. at 348 (considerations would be different for "factual misstatement whose content did not warn a reasonably prudent editor or broadcaster of its defamatory potential").

58. The trier of fact would have to assess the precise dimensions of the exclusivity requirement by delimiting the information available to the journalist upon reasonable effort. The lack of a reasonably available alternative source would render the information "exclusively" in the subject's possession. An alternative source sufficiently under the influence of the subject so as to be effectively silenced by him should be deemed within the subject's exclusive control.

The journalist would be expected to wait a reasonable time for a response. Because a loss of legal remedies may be at stake, this waiting period should provide sufficient time for the subject to consult with counsel. Nevertheless, the period should be flexible enough to accommodate the constitutional role served by reports of fast-breaking news. See note 14 supra (even temporary restraints may have irreversible consequences). Compare Curtis Publishing Co. v. Butts, 388 U.S. 130, 157 (1967) (plurality opinion of Harlan, J.) (article on football corruption "in no sense "hot news" ") with Associated Press v. Walker, 388 U.S. 130, 158 (1967) (plurality opinion of Harlan, J.) (companion case to Curtis Publishing) (news of desegregation riot "require[s] immediate dissemination").

59. Were a journalist to fabricate charges in detail, he conceivably could use the rule to induce disclosure of information. This danger is minimal, however, because the publication of unsupported charges might be proven to be substandard conduct even without the evidence of falsity that the rule would exclude. Cf. St. Amant v. Thompson, 390 U.S. 727, 732 (1968) (defense of lack of actual malice "will be unlikely to prove persuasive, for example, where a story is fabricated by the defendant, is the product of his imagination, or is based wholly on an unverified anonymous telephone call"). If a potential defamation plaintiff were fearful that proving fabrication would be difficult without revealing information he exclusively held, he could often rebut the charge through selective disclosure without revealing matters he most wished to keep secret. For example, a person accused of wrongdoing at location $X$ could refute the charge by demonstrating his presence at the relevant time at location $Y$ without revealing his activities at $Y$ if they were $\mathrm{cm}$ barrassing or private. 
The rule would function meaningfully only if the original accusations were made in considerable detail. ${ }^{00}$ Assuming such factual specificity in the journalist's accusations, neither a statement of "no comment" nor broad, conclusory denials would reserve a subject's right to introduce underlying facts at a defamation proceeding. ${ }^{61}$

\section{B. Advantages of the Proposed Rule}

The proposed exclusionary rule reflects the principle that protecting reputation through anything more than the minimum necessary restrictions on speech is contrary to the First Amendment. ${ }^{62}$ By restricting assessment of a journalist's inquiry to those facts available to him at the time of publication, the rule eliminates the prejudicial effect of admitting evidence of ultimate falsity unrelated to the determination of fault or actual malice. The standards of conduct for finding liability would be no more stringent in practice than Gertz intended. By focusing the defamation inquiry on factors within a journalist's control, the

60. A vague accusation could be met by an equally general response without sacrificing the right to introduce evidence of undisclosed facts. For example, the unsupported accusation, "[w]e know all about you, and you better confess," Jenoff v. Hearst Corp., 453 F. Supp. 541,549 (D. Md. 1978) (quoting defendant's reporter), could be met by the disclaimer, "no, I'm innocent," without the subject losing his right to introduce evidence detailing his innocence.

61. The proposed rule undercuts the force of an unsubstantiated denial coupled with a threat to sue by permitting only prepublication disclosures to influence the determination of fault or actual malice. Cf. note 41 supra (describing case of self-censorship in such situation under current law); Edwards v. National Audubon Society, Inc., 556 F.2d 113, 121 (2d Cir.), cert. denied, 434 U.S. 1002 (1977) (actual malice "cannot be predicated on mere denials, however vehement; such denials are so commonplace in the world of polemical charge and countercharge that, in themselves, they hardly alert the conscientious reporter to the likelihood of error").

The proposed evidentiary rule would restrict only evidence submitted by the defamation plaintiff. Arguably, it would be unfair to permit the journalist to introduce evidence of truth unavailable to him at the time of publication without permitting the plaintiff to introduce similar evidence of falsity. Yet if the article were true, such a result would be mandated by the truth defense, see W. Prosser, supra note 2, at 796-99, and possibly by the Constitution, see Cox Broadcasting Corp. v. Cohn, 420 U.S. 469, 497-500 (1975) (Powell, J., concurring) (constitutional requirement of truth defense implicit in Sullivan and Gertz standards of care). If it appeared that the article was false and that inequity might result from permitting the journalist to present selectively evidence of truth disclosed after publication without granting a corresponding right to the plaintiff, a court could infer a form of waiver. In such cases, presentation of postpublication evidence by the journalist would waive the proposed evidentiary restrictions on the plaintiff.

62. See note 4 supra. Although the proposed rule will be applied primarily in a news media setting, its functional justifications apply whether the party invoking it is an urban newspaper or broadcaster, a private pamphleteer, or a backyard gossip; communications by each spread information and promote diversity. Cf. Branzburg v. Hayes, 408 U.S. 665, 704 (1972) (freedom of press includes pamphleteer with mimeograph as much as large metropolitan publisher). The rule thus avoids the problem of defining and providing special privileges to an institutional press. See First Nat'1 Bank of Boston v. Bellotti, 435 U.S. 765, 795-802 (1978) (Burger, C.J., concurring) (identifying problems with theory that institutional press entitled to special First Amendment rights). 
rule permits a journalist to estimate in advance the practical contours of a fault-based standard. The added certainty that fault or actual malice will be the effective, as well as the nominal, standard of care reduces self-censorship to the levels warranted by Gertz. ${ }^{63}$

The exclusionary rule also protects the value of diversity articulated in Gertz by limiting the admissible evidence of an article's content to that necessary for determining fault or actual malice. The less judges and juries are influenced by the content of a defamatory statement, the less likely they are to employ legal remedies to suppress unpopular speech.

Moreover, by encouraging the journalist to confront the subject of an article with defamatory charges and encouraging the subject to disclose relevant information to the journalist, the rule facilitates resolution of a potentially defamatory dispute before publication. The reduced need for legal remedies minimizes the threat to diversity values that inheres in the defamation trial.

Similarly, the proposed rule encourages use of the self-help remedy identified in Gertz. ${ }^{64}$ By conditioning admission of evidence on its

63. Self-censorship occurs when publication decisions are made on the basis of potential liability. See note 4 supra. By granting the journalist greater control over his exposure to liability, the proposed rule would reduce self-censorship and enable publication decisions to be guided by journalistic rather than legal factors. See note 4 supra.

64. The proposed rule refrains from actually requiring disclosure of information, or from granting the journalist automatic access to the information. It simply requires a subject to disclose information in order to preserve in full force his defamation remedy. The subject confronts a similar fate at a defamation proceeding when he must choose between nondisclosure and a full legal defense. Cf. Anderson v. Nixon, 444 F. Supp. 1195 , 1199 (D.D.C. 1978) (plaintiff must disclose source for his "official harassment" claim if he desires legal vindication). The proposed rule imposes an additional cost to the subject only by encouraging him to disclose guarded information at an earlier moment. Even then, failure to disclose this information does not preclude legal redress, but mercly restricts the information admissible at a defamation proceeding. The First Amendment may permit a privacy action for public disclosures of truthful information. Compare Cox Broadcasting Corp. v. Cohn, 420 U.S. 469, 491 (1975) (leaving open possibility of public disclosure tort) and Briscoe v. Reader's Digest Ass'n, 4 Cal. 3d 529, 541, 483 P.2d 34, 42 43, 93 Cal. Rptr. 866, 874-75 (1971) (granting privacy right if matter not newsworthy and disclosure offensive) with Cox Broadcasting Corp. v. Cohn, 420 U.S. 469, 498 n.2 (1975) (Powell, J., concurring) (suggesting Gerlz abandonment of "public interest" standard undercuts basis of public disclosure tort) and Kalven, Privacy in Tort LawWere Warren and Brandeis Wrong? 31 L. \&. Contemp. Pros. 326, 335-36 (1966) (inquiring whether "privilege to serve public interest in news" has not become "so overpowering as virtually to swallow" privacy tort). If there is such a remedy, the proposed privilege provides greater protection of Iegitimate privacy interests than does present defamation law. The cost in privacy terms of revealing private information to a journalist before publication is far less than that of having to disclose it in defense of a defamation suit. If a defamation plaintiff releases private information at trial, it may be published with impunity. See Cox Broadcasting Corp. v. Cohn, 420 U.S. 469, 495 (1975) (state cannot impose sanctions for publication of truthful information contained in official court records). Yet if the same individual releases the information to a journalist privately, the journalist cannot publish it without subjecting himself to a suit for invasion of 


\section{Defamation Law}

availability at the time of publication, the rule encourages the subject of injurious charges to disclose information in his exclusive possession in order to retain his defamation remedy unimpaired. The rule thus provides the subject with an incentive to invoke the self-help remedy before publication occurs. Moreover, the rule encourages personal confrontation, a situation more likely than the public marketplace to result in a legitimate and effective rebuttal. ${ }^{65}$ When self-help succeeds in such circumstances, it protects reputation more effectively than the incomplete compensation provided by damage awards. ${ }^{66}$

privacy. Although disclosure of a private matter to the journalist alone raises some privacy concern, mass publication of such matter is a far more serious invasion of an individual's privacy. See Bloustein, Privacy, Tort Law and the Constitution: Is Warren and Brandeis' Tort Pelty and Unconstilutional as Well? 46 TEx. L. REv. 611, 619 (1968) (essence of privacy wrong is "that a private life has been transformed into a public spectacle").

65. A reply in a face-to-face situation, with its opportunity for informal discourse, is likely to be far more effective in redressing misconceptions than is a rebuttal addressed to a media audience. See Shiffrin, Defamatory Non-Media Speech and First Amendment Methodology, 25 U.C.L.A. L. Rev. 915, 934 n.140 (1978); cf. Green, Political Freedom of the Press and the Libel Problem, 56 TEx. L. REv. 341, 361 (1978) (direct charge to plaintiff himself gives opportunity for immediate confrontation).

66. See note 51 supra. Similarly, the exclusionary rule safeguards reputation more effectively than the right to reply or retraction approaches, see, e.g., Fleming, supra note 49 , without the concomitant infringement on editorial freedom, see, e.g., Bezanson, supra note 44, at 732-33; Stewart, "Or of the Press," 26 Hastings L.J. 631, 634 (1975). 